\title{
Embodied Pheno-Pragma-Practice- Phenomenological and Pragmatic Perspectives on Creative "Inter-practice" in Organisations between Habits and Improvisation
}

Wendelin M. Küpers, Massey University, Auckland, New Zealand

Email:W.Kupers@massey.ac.nz

\section{Abstract}

The purpose of this article is to develop a critical and extended understanding of creative practices in organisation from a phenomenological point of view. To develop such an understanding of practice, this paper will first outline a phenomenological understanding of creative practice, understood particularly with Merleau-Ponty as an embodied and situated nexus of action. Subsequently, the paper will show the contribution of pragmatism to an interpretation of practice as an experience-based reality and will describe the significance of habits. After briefly comparing common characteristics of both pro-experiential philosophies, some perspectives on a creative "inter-practice" and an inclusive "pheno-pragma-practice" will be explored. Furthermore, improvisation is discussed as a form and medium for the actual realisation of an embodied, situational inter-practice. Finally, some practical, political, theoretical and methodological implications and perspectives on creative pheno-pragmatic practices in organisation will be outlined.

\section{Introduction}

What makes practice in organisations creative? To what extent are creative practices and practicing embodied? In what way(s) can phenomenology, pragmatism, and a linkage between the two contribute to a more experiential and integral approach to creative practice in organisations? What roles do the body, embodiment, and habit play in creative action? Can improvisation be a medium for realising an embodied and creative "inter-practice" and what are implications? In response to these questions, this paper develops a phenomenological and pragmatic investigation of creative practice in organisations as part of the practice turn in organisation theory.

Generally, practice is a continually re-emerging topic in phenomenology (van Manen, 2007) and organisation and management studies (Küpers, 2009). There have been many attempts to deal with or overcome the so called "theory-practice-gap," emphasising either the supposed 
relevance of practice to research or of research to practice or taking a different tack and showing research to be a form of practice. For example, action research tries to bring theoretical inquiry and practical action together, focusing on the development of practical outcomes and new forms of understanding (Reason \& Bradbury, 2001, p. 2).

Furthermore, in the field of organisation studies, there are various research orientations following "practice-oriented approaches," trying to use "best-practices" or discussing various "practical implications." Diverse organisational and managerial phenomena are investigated as practices, such as the "strategy-as-practice" stream (e.g., Jarzabkowski, 2005; Whittington, 2003, 2006), and practice-oriented approaches have contributed to an extended understanding particularly of knowing and learning in organisations (e.g., Gherardi, 2000; Nicolini et al., 2003; Orlikowski, 2002).

There exist many distinct understandings of and approaches towards "practice" inspired by various philosophical theories. These include, among others, Wittgenstein's later philosophy (e.g. Schatzki, 1996) and Bourdieu's theory of practice $(1977,1990)$. Moreover, the notion of "practice" is used in different ways within the social sciences (Schatzki et al., 2001). Although there is not and probably cannot be a unified approach to practice, for many organisational researchers, practices constitute both the starting point, processed reality and end for which all understanding serves, including insights into effects and more general meanings.

Although many practice-based approaches are inspired by phenomenological interpretation, they have not been used systematically in a coherent and integrated way and especially have not considered the entwinement of life and world in practice (Sandberg \& D'Alba, 2009). Likewise pragmatism offers tremendous potential for the development of a more comprehensive understanding of practice for organisation theory (Schatzki, 2006; Wicks \& Freeman, 1998).

More specifically, both phenomenology and pragmatism can contribute to the reintegration of practice as embodied. Facing the prevailing separation of body and consciousness (Dale \& Burrell, 2000; Dale, 2001) and considering the "absent presence" (Leder, 1990; Shilling, 1993) and objectified appropriations of the body in social and organisational theory (Hassard et al., 2000), phenomenological and pragmatic philosophies can help to "re-member," i.e., reintegrate the marginalised body, embodiment and organisations (Styhre, 2004). This re-membering allows not only a critique of reductionistic understandings and approriating treatments of practices within a management of everyday life that prioritises instrumentally orientated action (Hancock, 2009), but re-integrates and open up to the lived, embodied experiences and processes, particularly relevant for inter-relational and creative forms of practicing. It also contributes to a "reflective practice" allowing reflection in and on action (Yanow \& Tsoukas, 2009) and re-integrates lived, embodied experiences and processes for a re-embodied organisation.

To develop such an understanding of practice, this paper will first outline a phenomenological understanding of creative practice, understood particularly with MerleauPonty as an embodied and situated nexus of action. Subsequently, the paper will show the contribution of pragmatism to an interpretation of practice as an experience-based reality and will describe the significance of habits. After briefly comparing common characteristics of both 
philosophies, some perspectives on a creative "inter-practice" and "pheno-pragma-practice" will be explored. Such understanding of practice allows a more inclusive approach, while understanding creative practice and practicing in organisations as a relational emerging event based on primordial and pre-reflexive dimensions. Furthermore, improvisation will be discussed as a form and medium for the actual realisation of an embodied, situational inter-practice. Finally some practical, political, theoretical and methodological implications and perspectives on creative pheno-pragmatic practices in organisation will be outlined.

\section{Phenomenology of Embodied Practice}

“Die Praxis steht überall und immer voran der Theorie” (Husserl, 1973, p. 61)

"Practice stands everywhere and always before theory"

\section{Phenomenological Understanding of Practice}

The contribution of phenomenology to an understanding of practice is based on the phenomenological call to return to things and events themselves and to their life-worldly situatedness and meanings (Holt \& Sandberg, 2011). Ontologically, this situatedness of practices encompasses placed dimensions (Küpers, 2010) and levels of durability as "contextuotemporal" realities (Elkjaer, 2000; Weik 2004). Within these spheres of the real enduring regimes of occurring events, activities and meanings are co-constituted. Phenomenologically, the life-world is the always antecedently given horizon for "all activities and possible praxis" (Husserl, 1970, p. 142). Correspondingly, practice in life-worldly organisations can be interpreted as an embodied and situated nexus of experience, action and meaning.

Based on his radicalised ontologisation of phenomenology and following a hermeneutic phenomenology for Heidegger (1962), practices are part of being-in-the-world ("In-der-Weltsein") that is embedded and immersed in the tangible day-to-day world respectively worldhood as an existentiale. Being in the middle of this world is situated and processed through "Dasein" $(\mathrm{Da}=$ there, Sein $=$ Being $)$ as a way of being $\mathrm{t} / \mathrm{here}$ as being and acting with its existential structures Dasein - as self-interpreting being and understanding (Verstehen), which is making sense of itself and everything else - exist in an ongoing structural openness in and projection "towards" the world. Its understanding reveals some actions of practice as possible or doable and as making sense, while others as not. Properly understood this Dasein is not as a substantial being - as an encapsulated mind or body - but as a shared, socio-historical existence or happening (Geschehen) as Being-in and Being-with. As such it opens up a world, a there ("Da"), from which beings can emerge as they "are." In turn, this meaning-world is itself constituted by practices, equipments, and social roles. Thus, being situated as Dasein, practices are part of the being-structure of being and as such permeate every aspect of our equipmental relationships, pragmatic activities and our social relations.

Phenomena and things are disclosed and understood that is found apparent intelligible, and meaningful within the horizon of Dasein's practical involvement with them particularly in a receptive "situated affectedness" (Befindlichkeit) or being-at-tuned (Stimmung). It is through 
this existential that phenomena are revealed as interesting or threatening as well as possibilities disclosed as attractive or indifferent.

Being part of "Being-in-the-world," practice is both a state of disclosing thrownness and engagement of Dasein as its essential ontological structures. The thrownness (Geworfenheit) understood as the non-beholding facticity of being delivered over and connected to a falling (Heidegger, 1962, pp. 174, 219-224) - makes practice "unfolding, fluid, ongoing, shifting, wholistic, and dynamic" (Weick, 2003, p. 459).

Engagement as a concernful dealing with equipment as encountered within the world refers to a ready-to-hand mode (German: "zuhanden", readiness-to-/at-hand, handiness: Zuhandenheit). In this mode practical activities do not consist of a separation between subject and object, while Dasein is available for action. "Readiness-to-hand is the way in which entities as they are in themselves are defined ontologic-categorically" (Heidegger, 1962, p. 101). Practitioners acting in this engaged mode are aware, handling and enacting interrelated resources, tools, tasks, projects and potentialities according to the coherence and connection (Bewandtnis) of their situated and instituted applicability (Heidegger, 1962, pp. 83-88). Furthermore, this acting manifest an "Umgang" that is actual involved activities and dealings with the world. To be pragmatically immersed in a worldly context and dealing with equipment is to have a certain knowing relation to the world with a particular concern (Besorgen) and circumspection (Umsicht) as modes of awareness. It is with this circumspective concern that Dasein sees things as ready-to-hand and being absorbed in micro-practices of everyday practical care and coping. Seeing things as ready-to hand entails the pre-predicative way that Dasein relates to entities in the world within a configuration of practical involvements that is an equipmental totality in use. This relating is showing our understanding of inherent possibilities while unthematically processing a usage or coping.

However, when experiencing an interruption an "unready-to-hand" mode appears. In this mode, Being becomes for example, conspicuous (unusable), obtrusive (missing) or obstinate (standing in the way). Experiencing unreadiness-to-hand as a deficient mode of readiness-tohand, can also be triggered by discoveries or mediate awareness for the need to shift relevancies or priorities thus take shape of a "neediness-to-hand" mode (Heidegger, 1962, p. 103).

It is through those moments of perturbations as disruption of or discovery in the day-to-day activities that practice announces itself as an explicit theme for thought and thus calling for to shift of relevancies. It is then that practitioners step back from their involvement and reflect on their practice entering a mode of present-at-hand (Vorhandenheit), akin to a more theoretical discovery, which involves a partial or total detachment of the "subject" from the "object" of meaning. As Zundel and Kokkalis (2010, p. 1217) noted:

When the smooth course of our unreflective practical dealings is disrupted, when equipment becomes unworkable for its particular use, when things are missing, or when they are standing in the way of achieving or completing the task at hand, understanding develops a new form that Heidegger (1962 [1927], p. 188) calls "interpretation" (Auslegung) in which possibilities of practical mattering are 
(made present and) disclosed in understandings that are "worked out" or "laid out” (Heidegger, 1962 [1927]).

In the ready-to-hand mode phenomena and entities, such as the use of equipment or coping are understood as everyday, pre-philosophical experience in non-thematic circumspective absorption (Heidegger, 1962, p. 107). Caused by a break of the referential totality of operations, in a present-at-hand mode, the same equipment or coping is perceived as conditional upon a reflective thematisation of and dissociation from the equipment and its serviceability. In other words, an entity can be understood as present-at-hand only once it has been "released" [entschränkt] from the practical configurations constituting its readiness-to-hand (Heidegger 1962 , p. 413) and appears then as "Being-present-at-hand-in-such-and-such-a-manner" (Heidegger 1962, p. 200).

Thus, this change of modes marks not only a redistribution of attentional resources, but also a shift from habitual ways of engaging with the world in which the phenomena disappears into its purposes to one, in which practitioners' look closely about what has gone wrong or why an activity has failed. The latter one implies a perception and concern for things not as they are used during the immersion in a field of practical involvements, but as they present themselves. Importantly, this thematising within the present-to-hand orientation, which amounts to an opening and re-contextualisation, emerges from and keeps assigned to the prior attitude and primordial praxis of involvement and care. In this complicity, practitioners experience wonder, surprise, shock, perplexity or bewilderment as existential anxiety within-the-world, out of which opens up the possibility of different ways of being. Yet, the existence of the entity and Dasein remains essentially constant across the changes-over in the way they are understood or impacts on the performance of further tasks and actions.

To lose this existential orientation, caring and grounding - e.g., due to taking modern techno-rational modes of occluding enframing and functionality as harmless and "natural," causing a flattening objectification of techno-scientific Dasein - leads to a levelling off and a falling into forgetfulness or oblivion of being ("Seinsvergessenheit").

A hermeneutical existential-ontological approach to practice allows seeing the world in a fresh way, allowing to wonder and to see opportunities and possibilities that were not available otherwise, disclosing or opening up new ways of being for example as a leader (Segal, 2010). Thus, being-in-the-world is the fundamental praxis of Dasein as movement in understanding possibilities that ground both the practical (poietical) and the theoretical. This primordial praxis means for Heidegger neither deed nor activity, but rather the sheer performance of life ("Lebensvollzug") and is part of his existential analytic which explores the relation of Dasein and temporality.

However, the deduction of this analytic of human being-in-the-world to temporal-historical facticity, the reduction of being-with ("Mit-sein") with others and the falling of everyday life into a transhistorical "they" ("man") can be seen as problematic. Narrowing the formal analytics to an existential of self-assertive Dasein, which in its decisionism of resolutness makes it ethically indiscriminate and the dualism between authentic or ownmostness and non-authentic ("Eigentlichkeit und Uneigentlichkeit") does not consider communicative existentials. 
Ultimately the being-with-others ("Mitdasein") appears for some critiques as remaining monadological and a-social. Heidegger's fundamental ontology appears as having a deficit of a normative-critical analysis with regard to a morally qualified and just communal life. ${ }^{1}$ Furthermore, the a-cosmic and a-historical tendencies in his later endeavour with its neopagan turn and mythologizing recourse to the archaic and calling of a eschatological advent of world destiny or impalpable destining of Being ("Seinsgeschicks"), the gnostic and apocalyptic hope of salvation, and the quietistic understanding of man as the "shepherd of Being" have been criticized (e.g., Ott, 1993).

Nevertheless, the invitation for keeping open (Offenhalten) the existence for what let us thinking (was uns zu denken heißt) and not to close up for basic questions of Dasein, but to trying to co-respond (zu ent-sprechen) to them (Heidegger, 1954), provides relevant perspectives for a responsive practice. Human beings are understood, by Heidegger particularly, as beings who answer the call of Being by relating in a herking way (horchend) the language of the intractable and indisponible event ("unverfügbaren Ereignisses") (Heidegger, 1959). Not confining the being-with-the-world entirely to a condition of "zuhanden" or "vorhanden" that is not relating to being neither unacknowledged means/tools nor theoretically presented things (classified, known objects, predicted events), phenomenology can help to become aware how phenomena are presenting themselves, in transition, unfurling, decaying, and remaining in their own care, rather than subject to the pragmatic care of those always relating to things instrumentally. Although this nexus is always enframed ("Gestell") - and at the limit of the finite to be transcended - the later Heidegger (1993) is calling for a release ("Gelassenheit") ${ }^{2}$ in order to keep open the clearing ("Lichtung") of Being.

However, considering Heidegger's relative neglect of the body (Aho, 2005; Schalow, 2006), practices need to be investigated as constitutively embodied, which is of specific relevance for an advanced phenomenological understanding of them as creative.

\section{Phenomenology of Embodied Creative Practices}

Like phenomenal practices in general, creative practices in particular are embodied, that is based on sensory, bodily, and emotional and mood-related processes. Thus, being or the unfolding of a creative practice is always already co-constituted by and relates to specific experiential dimensions. This is already alluded in the origin of the word, as etymologically the word creativity stems from the Latin word "creare," to create, which in turn is related to the Indo-European word "kere," that is "to make something grow" (Weiner, 2000, p. 8).

With the advanced phenomenology as developed by Merleau-Ponty $(1962,1995)$, we can recognise that creative practices are built upon an original, pre-reflective, ambiguous "ground" of primordial, lived experience and (inter-)corporeal relationships. As embodied beings, practitioners are both a part of the world and coextensive with it, constituting but also constituted (Merleau-Ponty, 1962, p. 453). This implies that practitioners can never experience creative practices, i.e., action or transformational encounters, independent of the practitioners' lived experiences ("Erlebnisse”) as bodily-engaged beings. 
The embodied practitioners as well as their socio-cultural embodiments are situated in a tactile, visual, olfactory or auditory way. Whatever they perceive, feel, think, intend or do, they are exposed to a synchronised field of interrelated senses and synaesthetic sensations (MerleauPonty, 1962, p. 207; Küpers, 2011). It is through an embodied living in the midst of a world of touch, sight, smell, and sound that the practitioners reach what they perceive and handle. There is an imperative for perception to become practical, for it is by acting upon things that we perceive them. According to Merleau-Ponty, sensing and perceiving in practice is an active behavior accomplished by the integrating body's postural schema as the recognizable sense of the body in orientation, movement, and rhythm. Moreover, practitioners act or cope while being situated spontaneously and pre-reflectively in accordance with their bodies and within their embodiment. For this reason, the embodied experience and practices are emerging within a genuine horizon on which they body-forth thus project their possibilities into the world, in which they are enmeshed.

From this perspective, bodies are a mediating nexus of experienced states and realities, action-inviting objects and activity-expressing subjects (agents), which are implicated in a creative be(com)ing-in-and-towards-the-world. Being bodily-subjects practitioners are always already thrown and engaged in the context of life; thus the origin of meaning for practice is found or discovered and created in and through their sense-giving senses (Küpers, 2011a) and embodied action in relation to their inhabited world. With an intentional and responsive orientation the actor or agent within the sphere of practice does not feel only "I think," but primarily "I relate to" or "I do" i.e., what s/he lives through with her "operative intentionality," preceding and conditioning the possibility of the "I know" (Merleau-Ponty, 1962, xviii, pp. 137, 173). In other words, our primary relation to our environment consists in performative and mediating competence, as the body possess a synthetic and coordinating power in relation by means of its practical action.

With this understanding of embodied-based practice, there is a close link between what is intended and what is actually given, leading to situated responsiveness, which itself is a specific answering practice (Waldenfels, 2007). It implies that as a living body and being embodied, practitioners respond to meaningful questions, problems or claims posed to them through embodied conditions and embedding contexts. Thus from an advanced phenomenological perspective, not only is practicing embodied, but being embodied is always already a way of practicing through lived situations. Within this situatedness, the living body intermediates between internal and external or subjective and objective as well as individual and collective experiences and meanings of creative practices. This body-mediated being and forms of embodiment coordinate the relations between individual behaviour, material, interpersonal social relations, particularly through language and communication as expressive media of interrelation (Merleau-Ponty, 1962, p. 197).

Accordingly, practices are a function and emergent process of a bodily subject and an embodiment of realities in which practitioners are embedded and actively and passively take part. Thus, creative practitioners and practices co-constitute each other; that is neither can exist without the other, as they are ontologically inter-related in a mutual entwinement. Embodied practitioners live out their acts and enactments by constantly actualizing and realizing their in itself embodied understandings. These understandings are already inhered in and possibly 
transcending actionable practices in inventive ways. In this way the "body-in-action" in creative practicing serves for a disclosure of the world and the creation and maintenance of meaning and signification. These insights have a bearing and can be supplemented by pragmatism and its interpretation of practice to which we turn now.

\section{Pragmatism, Creative Practice, and Situated Creative Action}

As developed and sustained by a set of major figures (e.g., Dewey, 1931; James, 1907; 2000; Mead, 1938; Peirce, 1931-58; Shook \& Margolis, 2006) and leading up to what we now call neo-pragmatism (e.g., Goodman, Putnam, Rorty) and further varieties (McDermid, 2006; Haack, 2006), pragmatism represents an influential body of texts and contexts for inquiring about creative practice. The significance of pragmatism and its focus on the "pragma" for organisation and management has recently found renewed attention (Küpers, 2009). Correspondingly, the practice - and action - related orientation of this philosophy is already manifested in the very root "pragma," meaning to act, "to do," or a deed or fact (from the Greek verb "prattein," referring to "experience," and " $\pi \rho \alpha \gamma \mu \alpha$," referring to "that which has been done," thus practice as a state of doing repeatedly, and which serves as the basis of the English words practical and practice). Consequently pragmatism has been defined by Dewey as the "doctrine that reality possesses practical character" (1908, p. 81). With its primacy of practice, unity of theory and practice, anti-Cartesianism, radical empiricism, instrumentalism, antirealism, and fallibilism, pragmatism treats theory as an abstraction from direct experience that ultimately must return to inform experience in turn.

As pragmatism stresses concrete facts, flexibility, experimentation, and practical, workable solutions to real-world problems, combined with its affinity for democratic consensus building and social justice, it appears to provide a sensible intellectual framework for practises in organisations at all levels. Consequently, pragmatism has served as the basis for various approaches towards the development of a theory of practice (and a practical theory), including, not only social theory (i.e., Arens, 1994; Joas, 1993; Rescher, 2000; Thayer, 1981) and economics (Bromley, 2006), but especially organisation theory (i.e., Schatzki, 2006; Wicks \& Freeman, $1998^{4}$ ) with its focus on work-practice in organisations.

Similar to a phenomenological approach to creative practice, according to pragmatic theory, embodied creativity implies being grounded in everyday, mundane experience and connected to ourselves, others, and our environment in an ongoing relationship. Complementary to phenomenology, pragmatism can serve as a base for a theory of situated creativity (Joas, 1996), in which creativity is present in all moments of action $\left(1996\right.$, p. 4). ${ }^{5}$ Like phenomenology, pragmatism also regards experience as fundamental to a practical understanding of oneself, others and the world. For pragmatists, experience is a complex stream of events, shaped by daily rhythms, full of currents and eddies, all interdependent upon each other. Because experience can - depending on its appearances and functions - take on so many gestalt-forms, figures and configurations, it needs to be interpreted in terms of its relations within a pluralistic and open "multi-verse" (James, 1895). 
In particular, Dewey's idea that transaction points to the reciprocal emergence of embodied self and world in organic interaction, constitutes an advanced attempt to surpass the dualism like that of body and mind, subject and object or emotion and reason (Dewey, 1931). From this standpoint, the actor, the action, and the purposes of them usually remain undifferentiated or fused within the act, yet each is part of a social act(ion). A social act refers to a social interaction that has become an institution or has a social structure with established positions like that between leader and follower, which is stable over time (Gillespie, 2005). Particularly in the more refined Meadian form of transaction, social process is highly relevant for practices in organizations (Simpson, 2009; Elkjaer \& Simpson, 2011).

\section{Embodied and Reflexive Habits and In-, De-, and Re- Habitualisation}

As habits are particularly relevant for a pragmatic understanding of creative practice, the following discusses different features and interpretations of habits and links them to phenomenology. According to Dewey (1922, pp. 22, 25) and other pragmatists (Shilling, 2008, p. 12), habits constitute the basic nature of the embodied self as a persistent tendency to be involved in the world in specific ways. Even more, they are the basic nature of body-mind unity of the individual as well as in relation to the body-mind nexus of other people. Habit, for Dewey, means "formation of intellectual and emotional disposition as well as an increase in ease, economy, and efficiency of action" (Dewey, 1922, pp. 46-58). Constituting (pre-) dispositions, habits refer to "a readiness to act overtly in a specific fashion whenever opportunity is presented (...). [Thus,] the essence of habit is an acquired predisposition to ways or modes of response (...)" (Dewey, 1922 [1988], p. 32). In other words, habits dispose one to respond in certain ways in certain circumstances; which implies that they are a way of anticipating one's own and others' conduct in a given situation as well as how a situation may unfold.

Being creative sense-mediating or experience-producing modes, habits constitute complexly structured reservoirs of stored actions, as they provide the capacity for treating different situations similarly. This implies not that habits are themselves the repetition, but make repetition possible. As constitutive structures of organised response, habits predispose a practice actively, in that they determine what we see, what we focus upon, and how we respond (Alexander, 1987, p. 146). Habits frame or establish a temporal context, a referential basis of interpretation and action. Thus habits are those forms of embodied creative agency shaping meaningful and purposive conduct that arise out of the "interaction between the organism or agent and the world" (Crossley, 2001, p. 137) and, as such, not only constrain, but enable and also enlarge the agential field of action (Dewey, 1922, p. 70).

Importantly habits are both pre-reflexive and reflexive. By their automatic nature, habits operate in a pre-objective and pre-reflexive manner (Alexander, 1987, p. 136), which refers to a level of embodied access to the world that is immediate and meaningfully tacit, temporally preceding cognitive thinking, linguistic formulation, and deliberate critical knowledge. The immediacy of meanings - which we have before we know them - is sensed in ways that are 
qualitatively distinct from knowledge and are evaluated through the operation of habit (Dewey, 1922; Kestenbaum, 1977).

This understanding of a habit-based body-forthing relation to the world is described by Merleau-Ponty in his interpretation of habitual bodies and in-habituated and in-habituating embodiment. For Merleau-Ponty habits are acquired and socialised skills, gestures, and techniques emerging from a social habitus, which rearrange and renew the corporeal schema (Merleau-Ponty, 1962, p. 142). ${ }^{6}$ This corporeal scheme refers to an incorporated bodily knowhow and practical sense, a perspectival grasp upon the world from the point of view of the body.

Importantly, habits are not a mechanical response, but rather a form of embodied and practical understanding or know-how which manifests in and as competent and purposive action, and which "attaches" to the world by way of the meaning it discerns therein. To acquire a habit is to grasp and incorporate, within the bodily schema and its tacit and practical principles (Crossley, 2001, p. 127; Merleau-Ponty, 1962, p. 146).

The habitual body-subject is already bound to a phenomenal field, which is the familiar concrete setting where things and embodied perceptions intersect immanently (Merleau-Ponty, 1962, xx). As perceptions are effectively shaped by a habitual stock of schemes and forms of implicit knowledge, all experiences within the life-world - as a habit-world - are structured through habitual ways of understanding and acting. The pre-reflexive reliance on habits for the basic practical grasp humans have upon the world is revealed when unusual circumstances render habits and assumptions inappropriate.

Correspondingly, habits immediately inform us of what is going on in concrete situations before we reflect on them. "Habit expresses our power of dilating our being-in-the-world or changing our existence by appropriating fresh instruments" (Merleau-Ponty, 1962, p. 143). As flexible skills for and of action and reaction, they then can be mobilised under different conditions to achieve different effects. Thus, it is a power of the pre-given past to make experience as embodied significance, which perpetually and pre-objectively imbues and informs the present and possible futures all mediated by the body. "Habit has its abode neither in thought nor in the objective body, but in the body as mediator of a world" (Merleau-Ponty, 1962, p. 145).

In the same vein, for Dewey: "Through habits formed in intercourse with the world, we also in-habit the world. It becomes a home, and the home is part of our every experience" (Dewey, 1958, p. 104). We dwell in habits - as hinted in the German word for habits "Gewohnheiten." Because we live in them, old habits are viable and powerful and die hard. With this dwelling function "habits are modes of connection to the world, shaping us and the environment according to their specific logic and affordances" (Shilling, 2008, p. 15).

Complementing the pre-reflexive dimension, habits can be also reflexive, as they enable interaction with the embodied self as a source of reflection and action, in particular when old habits get "busted" and replaced with new ones (Vannini \& Waskul, 2006, p. 191). The capacity to take up new habits, to break with the old when it gets in the way of desired trajectories of action or anticipated consequences, the habit of changing habits, shows the reflexive readiness for a transcendence of routine. This very capability to modify and refine existing habits and 
replace them with new, more promising habits refers to the pragmatist concept of reflexive habituality (Kilpinen, 2000, 2009). According to such reflexive habituality, habits can become de-habituated and re-habituated differently as forms of incorporations of creative practice. Moving between sedimented structures (stasis) and impulsive "non- or de-structure" (ek-stasis) it involves a de- and rehabitualising that is temporally dynamic, yet ordered.

While habit is a means towards expression and intelligent action, it is also capable of ossification into empty or dead routine (Alexander, 1987, p. 144). This happens in particular when habits remain static and lose their contact with creative sensation, affect and feeling as well as the variety and immediacy of a situation (Alexander, 1987, p. 45). In contrast to being a mindless repetition, i.e., mechanical and unresponsive way in which habits operate in a merely conservative and decayed, derivative mode of operation, intelligent and artistic habits can be dynamic structures, and as such connote flexible means of enlarging or expanding a situation. The potential of creativity is activated or called forth particularly when habits are interrupted (Joas, 1996), thus an unready-to-hand mode experienced. This interruptive disturbance provokes a questioning of goals and practices and allows the development of new patterns of thinking, feeling and acting.

However, instead of assuming a duality between creativity and habit it will be important to recognise their possible simultaneous presence in all moments of action (Dalton, 2004). For example, if occurrences' of spontaneity are cultivated and harnessed, a "routinized creativity" or creative habitualisation may develop or ensue, leading to a refinement or even perfection of the art of habitualised action. Such orientation requires overcoming separating body and embodiment from its embedding fields of action. To develop a post-dualistic vision of the constitution of body, self and society, according to Vannini and Waskul it is the movable habit of an ecstatic body or what they call "body-ekstasis" $(2006$, pp. 189, 192, 194) that entails the qualitative evaluation of one's body and embodiment as well as especially their aesthetic potential.

However, when ideologies become embodied merely in habits of passive recognition, a form of stasis results by which this dynamic potential of aesthetic evaluation is curbed and possibilities of the body-ekstasis stymied (Vannini \& Waskul, 2006, p. 197). On the other hand the potential for body-ekstasis is bred in the fertile dynamics of liminality. This liminal refers to a condition that is "neither here nor there," but "betwixt and between" (Turner, 1969, p. 95), and highly relevant for organisations (Küpers, 2011).

Essentially, habits are what enable us to engage in the world in new and different ways, thus transforming it, its practices and the practitioners involved. Particularly bodily habits offer a genuine way of inscribing practitioners in the world and of inscribing the world in their bodies. In this way incorporation and re-/inhabitualisation are interconnected (Weiss, 2008). When conventional habits cease to be effective or a specific disruptive crisis emerges, often socially mediated, creative actions help to establish new efficacious habitual relations with the environment (Shilling, 2008), thus "alter-native," i.e., "other-birthly" practices are co-created.

Thus habits neither determine the conservation of fixed, automatic routines nor the voluntaristic practices of unrestrained, uncontrolled acts of free will, but emerge from variable 
individual and social inter- and trans-actions. For this reason a study of habits and experiences need to consider especially the social sensitivities involved (Ostrow, 1990). Moreover, habits provide the conditions for meaning by not only approaching and assessing individual and social situations, but by also being the dynamic tools for transforming them (Alexander, 1987, p. 144). As such they are being part and an art of an experiential interpractice and improvisation for which both phenomenology and pragmatism help to understand.

\section{Pro-Experiential PrACTice: Phenomenology and Pragmatism as a Base for Creative Inter-Practice}

Although the approaches of phenomenology and pragmatism in many ways differ and diverge for example Merleau-Ponty's phenomenological anti-naturalism, and Dewey's pragmatic naturalism and biological holism and functionalism and experimentalism, poses problems for the methodological consistency (Aikin, 2006) - they also converge. Particularly they are similar and comparable in that they share the quest for a return to or a recovery of experienced practice (Rosenthal, 1980). For both philosophies experienced practice is understood as a practice of living, which implies forms and transformations of creative practicing. As both focus on (everyday) experience as a starting point, they are "pro-experiential philosophies." Sharing a criticism of atomistic and reductionistic views of the world, equally both aim for overcoming the antinomies of realism and idealism in ontology and of empiricism and rationalism in epistemology and generate possible practical and ethical implications.

Jamesian- and Deweyian-oriented pragmatism seems to be a kind of "protophenomenologism" (Edie, 1987), and, conversely, Merleau-Pontyian inspired phenomenology appears to follow a proto-pragmatic orientation (Küpers, 2009). Both concern a primordial immediacy of experience, which precedes the distinction between subject and object. Specifically, for both philosophies, to practice is to experience directly, immediately, implicitly, and comprehensively. Accordingly, for both philosophies practitioner, practice and act are not separated, but relationally intertwined in the actual experience. In other words, subjects as acting agents, objects as things acted upon, and actions and enactments are a nexus of relations in ever-shifting life-worlds and multiverses of complex relationships within a primordially continuous field of experience. Even more, experiencer and experienced, knower and known, actor and act or practioners and practice, as well as creator and creation are inextricably entwined from the beginning and throughout the ongoing social process. For both pragmatism and phenomenology, embodied experiences, interrelations, connectedness, transactions, and entanglements are all constitutive of reality and thus of creative practicing as a development of entwined mediating of being and becoming. This joint relational understanding of practice and creativity as inseparable serves as a base for what can be called "inter-practice".

Following a processual turn towards the relational nexus of practices with its focus on the inbetween, creative practice can be interpreted as an "inter-practice" (Küpers, 2009). Such an orientation understands creative practice and practicing as an emerging event, which is always already based on primordial and pre-reflexive dimensions. Accordingly, inter-practices are coconstituted and continuously influenced by pre-subjective, pre-objective dimensions. These primordial pre-reflexive dimensions of "inter-practice" refer to ways creative practices are 
processed by pre-discursive capacities and non-abstract experiential processes, particularly of organizations as well as their members and their complex inter-relationships and organising.

Furthermore, due to its proto-integral and relational orientation, advanced phenomenology of action, and a relational oriented pragmatic action inquiry ${ }^{7}$ reveal the interrelationship between being, feeling, knowing, doing, and effectuating, individually and collectively. With such an orientation, both phenomenology and pragmatism are suitable for exploring the interplay among subjectivity, intersubjectivity, and objectivity, implies the conceputalisation of alternative epistemological and methodological reflections and actions (Torbert et al., 2004; Küpers \& Edwards, 2008). Moreover, these interplaying relationships correspond not only to epistemological issues, but can be ontologically linked to complexities of human action and system's function in organisations with their different territories of experiences related to bodies and embodiments of an organisation as an institutionalised "incorporation." These phenomenal fields not only include attentional, intentional, cognitive and emotional processes, but also responsive and enacted behavior and performances, as well as action-logics (Torbert et al., 2004). All of these elements of a creative inter-practice are co-determined and co-emerging on a collective level by an organization's culture, values, strategies, structures, and functions. Conversely, without action, any of these spheres and their inter-relations would be meaningless. Therefore a comprehensive and relational understanding of creative inter-practices needs to cover all these interplaying dimensions.

Thus inter-practices in organisations made up of a collection of pre-reflexive orientations, intentions, thoughts, feelings, activities, and tools as well as shared activities, habits, and routines (i.e., Feldman \& Rafaeli, 2002) of practitioners as the performing human actors (or agencies), realising practical purposes. Correspondingly, an adequate practice-oriented research requires consideration of "praxis," which refers to the actual activities occurring within a situated field and a gestalt of acting and enactment. This praxis is not simply action based on reflection or mere activities, as acting upon or doing to, but is also constituted by an embodied and creative acting and being acted upon. As such, praxis include, besides an intentional focus, also engaged, reflexive commitment and dialogical responsiveness as well as practical judgements about how and when to act in a given situation. The forms of particular practices can vary with changes in worldly situations and their structurations. For this reason, practices are not singular and unitary, but multiple and contingent. Being implicated within various horizons, practices are not and cannot be closed. Rather they are evolving processualy towards temporary results, thus are always incomplete and open. Accordingly, practices include simultaneously the context, the process and the "outcome" of interconnected material, personal, interpersonal and institutional dimensions or relationships that transpire through them. In this sense they are multidimensional and inter-relational events which call for and require an integral understanding and approach. Bringing together insights from phenomenology and pragmatism in the form of a "pheno-pragma practice" contributes to such an integral endeavour.

\section{Perspectives on Integral "Pheno-Pragma-Practice”}

"Pheno-pragma-practice" can be interpreted as a special employment and "application" of advanced phenomenology and pragmatism for developing an appropriate understanding and a 
methodological approach towards creative practice in organisational settings. Correspondingly, pheno-pragma-practice strives to make accessible, describable, and interpretable the implicit and explicit dimensions of the inter-related creative practices of individuals, groups, and organisations. Without dealing with various specifics of an integral pheno-pragma-practice here (Küpers, 2009), the following outlines some of its forming qualities and implications for preparing the subsequent discussion on improvisation as enactment of creative practice.

Based on the outlined phenomenological and pragmatic insights, the creative practice of pheno-pragma-practice is interpreted as an embodied, experiential, inter-relational, as well as actionable process. Accordingly, modes of creating within pheno-pragma-practice are part of the lived practices of bodily and relational realities that manifest in practical actions. These actions in turn are sedimented in habituations, habits, and kinesthetic memories of the individual body respectively embodied collective memories. Importantly, creative actions are not only reactions or responses to situated habitual modes, but they also co-create via de- and rehabitualising new habits and inhabitualised practices in and of the being-in-the-world. Accordingly a joint phenomenological and pragmatic interpretation of creative practice aims at opening up possibilities for emerging formative relations between being and becoming, feeling and knowing, and acting and being acted-upon, between practitioners or who they could be(come).

In this way pheno-pragma-practice is part of various formations. It is pre-formed, that is, preinformed by sediments, previous experience, and tacit and implicit knowing and pre-forming by giving significance and making sense or letting sense be. Furthermore such a practice is being per-formed in specific ways of enactment. Moreover it in-forms by knowing about the practice reflexively; that is, it conveys information about appearances and appropriateness, and consequently, if recognised as insufficient, re-forms, that is, changes and adapts its outer forms of actual acting. In a more radical sense it also may trans-form; that is, it alters profoundly its formation and formative configuration of actual and possible action, opening up for potential alternative pre-formations and per-formances and so on in a continuous spiral of unfolding.

Accordingly, with regard to a theoretical and methodological orientation, what van Manen (2007, p. 26) described for a phenomenological understanding of practices becomes also important for a pheno-pragmatic approach, in that it likewise formatively informs, reforms, transforms, performs, and preforms the relation between being and practice, including that of research. In-formatively, phenomenological and pheno-pragmatic studies make possible thoughtful advice and consultation. Re-formatively, phenomenological and pheno-pragmatic texts make a demand on practitioners, changing them in what they may become. Transformatively, phenomenology and pheno-pragmatics have practical value, in that they reach into the depth of being a practitioner, prompting a new way of becoming. Per-formatively, phenomenological and pheno-pragmatic reflection contributes to the creative act and to the cultivation of tact (van Manen, 1991). Finally pre-formatively, phenomenological and phenopragmatic experience gives significance to the meanings that influence practitioners before they are even aware of their formative value.

Methodologically, a pheno-pragma-practical approach with its formative dimensions is relational, in that it looks into the in-between, perceiving the patterns of connected interrelation- 
ships of creative practices - how they appear on the horizon and travel over the infinite ocean of possibilities. With this emphasis, pheno-pragmatic theory reflects (transcendentally) the conditions of possibilities or impossibilities and recognizes the multiplicity and interdependencies of poly-causal forces of creative practice and practising as they unfold in an ongoing dynamic process. As a processual approach, pheno-pragmatics helps to overcome the problems and limitations of a conventional phenomenological orientation ${ }^{8}$ as well as atomistic and mechanistic or substantialist orientations of modern thinking and to simultaneously provide empirical access to actual life-worldly practice. To avoid reductionist fallacies, a comprehensive pheno-pragma-practice requires a multi-level analysis based on an integral view, which systematically considers various perspectives on organisations and their living practices as holonic processes (Küpers, 2009). ${ }^{9}$

Bringing together insights about practice from phenomenology and pragmatism, a phenopragmatic understanding of creative practice avoids both the reductionisms of a one-sided constructionism and practicalism. From a pheno-pragmatic perspective, constructionist approaches to practice tend to reify what eludes reification - as a form of social and cultural anxiety of late capitalism (Bewes, 2002) - while trying to bring practice within the reach of objectivistic thought. With their tendency to deny or undervalue the importance of the phenomenal world and by insisting on the textuality of phenomena, many forms of constructionism do not provide access to or a vocabulary for studying the pre-reflexive dimensions and depth of embodied human experience and creative practice. Disembodied discourses of constructionism tend to privilege symbolic signifying (semantic) media, while neglecting or glossing over the corporeal, that is, somatic forms of signification. Social constructionism and its conceptualisation of knowledge are tending to be an over-socialised epistemology. They have also been criticised with regard to problems of social overdetermination and unfounded relativism (Schmidt, 2001) and the danger of loosing the ability to supply credible and nuanced explanations (Hacking, 1999).

Although constructionism - with it breadth and variety of forms and applications (Hacking, 1999, e.g. Schuetzian, Berger/Luckmanian or Vygotskian versions) - is helpful to understand how historically and culturally contingent phenomena arise in social worlds, the status and claims of constructivism and social constructionism are in some ways in conflict with advanced Merleau-Pontyian phenomenology and ontology. Both research orientations share an antinaturalist or anti-essentialist view as well as a perspectival approach towards understanding and similar methodological orientations. However, phenomenological ontology does not follow the constructionists' tendency towards an anti-realistic stance, and emphasis the constitutive dimension. Phenomenologically, the world is one that is always already there before any reflection begins and constructs are made. Hence: "The real has to be described, not constructed..." (1962, p. x). For Merleau-Ponty the task is not to construe the world; rather interrogating it to reveal the Beingness of the world and also how phenomena are constituted as constructed in the same. The task of phenomenology is make intelligible and "to describe, and not to explain or analyze" (1962, pp. ii/viii) the field of Being interpreted both as embodied topography as well as historically and culturally contexualised, articulated and transformed space. It would have been worthwhile to critically compare and discuss inhowfar (or not) a social or relational constructionism perspective - like phenomenology - recognise that construction arises from an intimate dialogical relationship between our embodied being in the 
world and how to make sense of that constitutive meaningful holonic embodiment and what methodological and political implications can be derived from those "Telling Tales of Relations" (Hosking, 2011).

Furthermore a reductionism manifests as a short-sighted "practicalism" which, due to an outcome-fixation and utilitarian course, collapses the "pragma" of instrumentalism with practicality. Such an orientation implies the loss of a sense of emergent processes, un(pre-) determinable qualities, and ethically reflexive dimensions, which a pheno-pragmatic orientation, in contrast, considers systemically and systematically. Like pragmatism, the pheno-pragmatic offers more than simply a utilitarian orientation, while it integrates ethical spheres of practice. Such orientation opens a space for continual inquiry and ongoing reflection that enables possibilities and choices for ongoing changes in practice, including compassionate action (Doane \& Varcoe, 2005). Furthermore, pheno-pragmatic approaches are critical of the dominance of technocratic ideologies, thoughtless calculative rationalities, ${ }^{10}$ and exploitative orientations and of the inherently instrumental presuppositional orientations and policies or structurings of many organizational and managerial practices.

A pheno-pragmatic approach can show how an absorption by instrumental preoccupations and reductionistic practices not only leads to preconceiving all entities as intrinsically meaningless resources, merely awaiting optimization, but that such an orientation is silencing possible practices or impoverishing and undermines potential creative engagements, which are realized particularly during improvisations as a form of an enacted inter-practice.

\section{Improvisation as Enacted Inter-Practice}

The gained phenomenological, pragmatic, and pheno-pragmatic understandings of habits and the inter-corporeality of co-creational action and passion as mediated through the creative interpractice of pheno-pragma-practice are brought to life and can be realised by processes of improvisation. Improvisation is a kind of situational and relational process, inventive competence, and responsive, performing action, which takes place in a spontaneous and intuitive fashion in specific circumstances and contexts (Crossan, 1998).

But for being a general power to act in an embodied way always require to be situated in historically contextualised ways. Thus, improvised practices as individual and social interactions and inter-passions in real-time are always embedded within specific materially, structurally, and culturally embodied con-texts of relationships. This implies that creative practices of relationally embedded improvising agents are informed, constrained, and possibly also codetermined by the social structure of the performance (Pinnington et al., 2003). As part of these structures, creative improvisational inter-practice involves constant organising, disorganizing, and re-organizing and moving between subjective and objective realms. Correspondingly, as an integral practice improvisation not only helps to adapt to complex outer environments, but also allows expression of inner complexity (Montuori, 2003).

To process these complexities and to be effective, spontaneity and improvisation must be anchored in habitual patterns of behaviour, which are constituted by both oneself and others. As 
relatively stable patterns of behaviour, and sedimented meanings (Merleau-Ponty, 1964, p. 89) consisting of past layers of experience - habits offer the spontaneity of improvisation the permanence it needs for a continued and sustained existence, establishing perspectives and giving a temporal continuity for the lived body.

Freedom would be meaningless without the power of conservation embodied in habits; only their mutual interdependence can have a sustainable bearing on life. If decisions are to take root in life and be meaningful, they must achieve durability with ways of perceiving, feeling, thinking and acting. Thus relating to practical, patterned contexts in which the lived body can continually operate is to incorporate habits, which have been discussed before.

Furthermore, the improvisational acts of creating new meanings via the previously outlined de- and rehabitualsations imply also anticipated or imagined present-future relationships. To paraphrase Kant and Hamrick (1974), improvisation or spontaneity without habit is empty; i.e., of enduring commitment, while habit without improvisation respectively spontaneity is blind; i.e., without orientation to new situations and futures. With sedimented habitual pasts, continuities with the present, as well as imaginative future perspectives, improvisation follows particular temporalities. Improvisation then, although based on past habits and intentional ${ }^{11}$ in nature is also ex-tempor-aneous ("ex tempore" = outside the normal flow of time) - that is, happening un-predictably and with little known cause or causal relationships. It does not belong to a regular chronology in a linear sequence of events where each "now" lies on a continuum between the "already been" and the "not yet now," but processes an authentic temporality (Ciborra, 1999).

In this sense, improvisation is an ecstatic experience, an irruption, which is characterised by a sense of immediacy, suddenness, and surprise, transgressing pre-determined plans. Thus, impulses, as they emerge in improvisation, can be creative by being de(con)structive, innovative, or seemingly foolish, a-rational forms of action. Accordingly improvisation may emerge, particularly from desires to interrupt or to vary habits and routines. However creative practice as realised in improvisation is not only a reaction to the disturbance of previously successful routines, but can also be the result of conscious attempts at improving habitual actions, making them or corresponding routines more effective, even if the routines had been generally successful (Dalton, 2004).

As much as the creative inspiration of improvisation occurs outside of time, to be effective in the world it must be sustained in time. Thus, in addition to a momentary eruption in time, creative improvisation needs to become part of an embodied interpenetration of past, present, and future, integrating the tempo of passing moments with the temporality of passing months or years.

To form and reform habits improvisationally, requires an experienced self and community, not in the sense of a static collection of attitudes, knowledge, and competencies, but in the dynamic sense of experiences as a dialectic interplay between being and becoming sensitive to the qualities and intensities of situations. Thus, possibilities of improvisation are "born of habit" (Merleau-Ponty, 1962, p. 238). Improvisation plays around and alters habitual structures/forms 
and their usage in creative ways that also enable change of structural foundations and forms of per-formance (Hatch, 1999, p. 5). However:

Improvisation is not breaking with forms and limitations just to be "free," but using them as the very means of transcending ourselves and yielding intensity. If form is mechanically applied, it may indeed result in work that is conventional, if not pedantic or stupid. But form used well can become the very vehicle of freedom, of discovering the creative surprise that liberates mind-at-play. (Nachmanovitch, 1990, p. 84)

During improvisation the in-habited "world" and its habitual realities or practices are reconfigured, and the order and meaning established by given conventional procedures are disrupted as a consequence of the irruption of an authentic "Being" an experience that would otherwise remain inhibited or latent in the everyday world of procedure and routine (Ciborra, 1999).

As a situational process improvisation is "embody(ing) different senses of persons in different situations" (Machin \& Carrithers, 1996, p. 345) and is performed often unexpectedly. Thus, it can be highly contingent upon emerging circumstances: design and action (Weick, 1998) and ways of interpretation. Correspondingly improvisation is an ambivalent phenomenon: simultaneously rational and unpredictable, planned and emergent, purposeful and blurred, effective and ir-reflexive; a genuine fusion of design and execution, of unintended change and order; only discernible after the fact, but spontaneous in its manifestation (Nachmanovitch, 1990).

Processually, improvisation stresses the importance of "adapting" while acting which refers to the ability to think while doing or as the common idiom says "to think on one's feet," rather than just following plans scripts, routines, standard processes etc. This unique capacity is described by Weick (1998, p. 549) as "flexible treatment of pre-planned material" and "acting your way into eventual understanding." In this way Weick suggests that planning and improvising are not mutually exclusive, but that an appropriate balance between the two is needed. Improvisation will occur in organisational contexts, so practitioners need to decide how much is wanted and how to facilitate what Ciborra (1999) calls "smart improvisation" or improvisation by experts that helps to secure organisational goals.

With these qualities improvisation refers not only to a given situated action, but to an ongoing creative practice as it unfolds, thus being responsive in real time (Crossan \& Sorrenti, 1997; Crossan, 1998). This implies that improvisers or improvising agents, for example, individuals, groups or entire organisations (Miner et al., 2001) develop their improvisational responses while acting on situated problems or opportunities. Also, for these reasons the appropriateness of improvisation can only be evaluated and judged in hindsight, not by foresight as in traditional planning. This quality can be traced back to the Latin root improvisus, meaning unforeseen, which is in fact to create and deal with surprise. The implicit embodied, irruptive, and responsive character of improvising implies that it defies measurement and systematic objectifying approaches and methods. 
Correspondingly, the subversive power of improvisation can be found in its challenges to the prevailing objectivist and cognitive paradigm, which governs many organizational practices, and particularly its theorizing. To improvise demands abandoning the neat, artificial worlds of models, structures, and univocal meanings. Rather instead it requires entering the world of ambiguous experiences in the everyday life of organizations, particularly in the context of change and its supposed management (Orlikowski, 1996). During improvisation, creative practitioners in their inter-practicing can come authentically and openly to the fore, read and enact the life-world in novel ways, make swift and resolute choices and engage in truly enterprising action or entrepreneurial bricolage (Baker \& Nelson, 2005; Duymedjian \& Rüling, 2010) of material, mental, social and cultural resources. Thus, improvisations are instances of situated inter-practice-making and practice-changing, and as such are forms of what could be called "re-evolutionary (dis)-organising."

\section{Implications and Conclusions}

The outlined pheno-pragmatic approach to creative practice and its interrelations entails practical, political, as well as theoretical and methodological implications.

\section{Practical Implications}

With its experiential, dynamic and provisional status the described forms and transformational qualities of creative practice defy control and elude a straight manageability. Because creative practice does not exist as a given, stable, fixed entity, it cannot be simply organised, managed, or manipulated. Instead of being designed directly, creative practices and particularly improvisations can only be designed for, that is, allowed and encouraged. Part of this challenge is to prepare and create favourable circumstances, supporting contexts, and relationships that engender conditions by which creative inter-practices can flourish. Required for the unfolding of creative practices and "inter-practicing" are enabling possibilities for developing or upgrading embodied forms of creative realities in every-day work-life. These comprise targeted facilitations, creating specific circumstances for each "pheno-practical" sphere on a situationspecific basis, integrally, which can be specified in more detail (Küpers, 2009), but are beyond the scope of this article.

Particularly improvisation, as a disciplined craft of pheno-pragma-practice requires situationally applied skills that can be learned through continual practice (Crossan et al., 1996, p. 25), as "...improvisation has no existence outside of its practice" (Bailey, 1992, p. x). To practice improvisation (Mirvis, 1998) individually or in "communities of improvisation" (Machin \& Carrithers, 1996) requires special encouragement and conditions to be fostered, such as the cultivation of creative habits (Tharp, 2003), or teams training for improvisational action (Vera, 2002), and the assessment of success not according to degrees of conformity to existing plans. Instead expectations of active deviations from the plan are needed, rather than seeing them as a symptom of failure (Orlikowski \& Hofman 1997, p. 20). 
But there are powerful counter-forces restricting such improvisational ventures, acts, and creative practices in the actual organisational world. The pervasive thirst for predictability, functionalism, and governance in modern organisations may undermine a lot of the described creative potential of improvisation. This can be experienced by anyone who is not conforming to written rules, plans, ideals, blueprints, or other "rational" problem-solving methods. The "art" of improvisation and "the aesthetics of imperfection" (Weick, 1995) in response to errors of reach, failures, flaws, dissonance, traps, etc., are not acknowledged or appreciated as often as pretended and denigrated directly or subtly.

To realise embodied, improvised, thus creative practices, improvisers need to have access to and draw upon available material, infrastructural, financial, cognitive, affective, emotional and social resources (Cunha et al., 1999). All of these resources and the described facilitating conditions are closely related to political implications.

\section{Political Implications and Critical Reflection}

By enacting the mentioned facilitations and other issues of realising creative practices it will be important to consider that pheno-pragma-practice is not a value-free process. While it is intended to contribute to the flourishing of the interrelated human persons, communities, and systems, it raises questions of values, morals, and ethics. Consequently there is a need for appropriate attention to underlying principles and purposes, being as transparent as possible about the strategic and moral choices that are made. However providing reliable guides to the question "useful for what?" is actually rather complex, because it immediately raises critical issues such as: Who defines what is wanted and whether it is known what is wanted? Whether what is wanted is actually good and for whom? Who is the assigner to consequential actions and how are they evaluated? Furthermore: What are the repercussions for various stakeholders involved? What about the long-term considerations beyond immediate concerns? Therefore the question is not simply one of "Does it work?" or merely direct "outcomes-based" measures, but one of integrating practical issues within broader circumstances, so not to fall into the fallacy of a individualist heroic agentic orientation or collective action-orientation, which could have suboptimal or dysfunctional effects in the integral nexus of practice.

Furthermore, some practices may become entrenched among the others more dominantly, so that some practices become "more equal than others" and end up anchoring nets or nexuses of activity (Swidler, 2001). A pheno-practical approach requires critical analysis of the ways in which political practices in organisations are related and exercised to achieve and maintain power and control in organisational settings by which certain practices are excluded or superimposed. This refers to a critical investigation of how individuals' specific subjective experiences, meanings and corresponding practices are discriminated, marginalized, degraded or ignored, silenced or dominated, subordinated or disciplined. A pheno-practical approach can be used for studying critically the ordering and normalising of disciplinary techniques and encumbering processes of imposed practices on the collective level. These may include the use of power for directing and controlling norms or governing functional and structural issues within the organisational system.

Furthermore, tactics and the micro-political processes in relation to the everyday of living (de Certeau, 1984) in organisations can be studied as an employment of a creative intelligence and 
practice of governance by the occupants of work environments or resisting groups to subvert all-pervasive pressures in order to re-assert and re-appropriate a sphere of autonomous action and self-determination. These tactics - understood as "art of the weak" - are based on complex intersubjective relations of sociality, intimacy and affect and take advantage of opportunities through playing with "strong strategies." De Certeau's interpretation of tactics helps to reflect on the encounter between the plurality of everyday practices with its irreducibility and unintelligibility and the narratives of and at the margins. By engaging with the Other within immanent and everyday practices, de Certeau foregrounds a political ontology that sees otherness as the starting point to take the very irreducibility of everyday practice as a creative challenge. Nevertheless, this irreducible practice can be translated into ethnographic practice and by this explore narrative human subjectivity in more nuanced and ethically engaged ways (Napolitano \& Pratten, 2007).

Additionally, using a pheno-practical inquiry can diagnose various problems, pathologies and conflicts concerning one-sided or fixating processes of practices as well as providing ways for dealing with them. By applying varied perspectives and their interconnections, pheno-pragmapractical researchers are better equipped to shed light on tensions that come along with lived practices by, for example, exposing conflicting demands and disparities as complementary and by demonstrating that apparently opposing interests are actually interwoven. This is apparent for example in the conflicting demands between share-holders versus stake-holders in the context of sustaining and sustainable more responsible business (Küpers, 2012).

As part of a critical reflection concerning various difficulties, limitations and problems involved in realising the embodied creative practices, there is also the need to consider the danger of a kind of regression. While there is an increasingly urgent need for reviving forms of experiential creative practices of embodiment, there exists the threat of falling prey to a premodern longing for unity and retro-romantic fallacies or irrational sentimentalities. As understandable as a yearning for returning to a pre-reflective union for the disembodied, alienated, rational modern and fragmented, relativising consciousness appears, there is no way back to a retro-regressive coincidence with nature or supposed pre-existing truths. Rather, what is required is an adequate and integral orientation and practice of transformation (Küpers, 2010) which follows a co-creative way forward or cyclic movement spiralling back and forth with a reflective somatic consciousness (Shusterman, 2005). ${ }^{12}$

\section{Theoretical and Methodological Implications}

Regarding theoretical and methodological implications and future research, the proposed phenomenological approach and pheno-practical, integral and processual framework provides bedrocks for more rigorous theory building and theory testing. In terms of methodology, a pheno-pragmatic approach offers alternative approaches for understanding the intricate nature of the processes and patterns of practices in organisations. Pheno-pragmatic research can bring the researcher in closer touch with the "real-word" of practice processes, while recognising the heterogeneous dimensions involved. As reminders of the life-world's multifaceted wholeness, phenomenology, pragmatism and an integral pheno-pragma-practice serve as helpful antidotes to partial views and reductionist methods. A critical pheno-pragma-practical reflection is very 
much aware of the limitations and dangers of constructing a convenient unifying scheme in relation to lived experience.

For researching lived experiences (van Manen, 1997), the pheno-pragmatic model is just a map of perspectives, not to be confused with any ontological territory. As an always preliminary, heuristic means, pheno-pragmatic modelling does not refer to an epistemically prior, unerring recipe or scheme that ensures compelling propositional results. Rather, the methodology of an integral pheno-pragma-practice follows the literal meaning of "method" as "following along a way," i.e., "meta ton hodon." Accordingly, it refers to the path that phenopragma-practical thinking itself tentatively inscribes in attempting to disclose phenomena. For this reason the actual course of pheno-pragma-practical research needs itself to be seen as a lived experience and embodied research practice, notwithstanding following specific qualitative criteria for ensuring scientific rigor and critically linking it to approved methods of research. In this way an empirically tested pheno-pragmatic approach could contribute to re-examining the implications of variations in techniques of qualitative approaches can be complemented by rigorous empirical methods for generating quantitative findings and multiple triangulations (Jick, 1979), including longitudinal studies and multiple case studies (Yin, 1994) and sensuous and art-based or methods (Küpers, 2011a).

An extended phenomenological epoche, as suspensive method applied to organizing would not, as in Husserl, to bracket off the world in order to discover the pure, worldless that is decontextual structures of consciousness and essences, but rather, as in Merleau-Ponty, to use the distance supplied by the reduction as a heuristic device to reveal and interpret the genuine organising process with its non-cognitive constituencies. By creating descriptions and interpretations of actual experiences pheno-pragmatic organizational researchers can develop a much-needed a-causal, non-reductionistic and non-reifying approach towards a post-Cartesian understanding of the underlying intertwining. ${ }^{13}$

Of course, phenomenology and pheno-pragmatic orientation itself is only one method or approach among others; and therefore not privileged to the foundational status as e.g., Husserl sought, as no position can claim in a world of conflicting and contested interpretations. A selfcritical phenomenology and pheno-practice must explore crucially its own phenomenality and relativity as one form of gaining knowledge and truth among others. Part of this necessary reflection is the effort to examine critically its own scope and limits and determine its meaning and ground. Accordingly, the processes and "results" of phenomenology and pheno-practice have their force, not as a set of fixed claims passed on as correct doctrine, but as an interpretation of meaning appropriated and renewed in continued questioning and interpretation. In particular they "offer an alternative to managerial, instrumental, and technological ways of understanding knowledge, and they lead to more ethically and experientially sensitive epistemologies and ontologies of practice" (Adams \& van Manen, 2008, p. 615).

In this way pheno-pragmatic research points to possible pathways, which may lead conventional research out of their self-made enclosures of methodological devices and habitroutines that are binding scientific conceptualisations, understandings and interpretations. For example, in addition to phenomenology-oriented first-person perspectives (Giorgi, 1997), it would also be interesting to extend research systematically towards second- and third- persons in singular and plural forms to understand the complex relational dimensions of practices in 
organizations and leadership (Torbert et al., 2004). Moreover, a critical phenomenology may contribute constructively to the contemporary epistemic odyssey of organisation science, as a passage between Scylla - the rocks of dogmatic modernity - and Charybdis: - the whirlpool of dispersed post-modernity.

Content-wise, for a further application and development of the pheno-pragmatic model it would be challenging to link the outlined specific different dimensions with those of knowing (Küpers, 2005) and learning (Küpers, 2004, 2008) and how they inter-relate reversibly to each other. In particular it would be interesting to explore pheno-pragmatic practice in relation to concepts of implicit and tacit knowing (Polanyi, 1966, 1969), ${ }^{14}$ narratives (Küpers, 2005), as well as implicit and transformative learning (e.g. Berry, 1997; Reber, 1993; Gunnlaugson, 2005). Furthermore research on improvisation and play would be worthwhile, as both are embodied and creative performances as an "immersion-in-activity" (Hyland, 1984) and the implicit "the logos of the aesthetic world" (Merleau-Ponty, 1962, p. 429) by which imagination and creative inter-practicing is mediated and unfolds.

\section{Conclusion}

By following phenomenological and pragmatic inquiries this paper reconceived practice as an always already embodied and experiential event, and then the significance of bodily and reflexive habits were shown. Based on phenomenology and pragmatism with their proexperiential and transformational orientations then potentials of a creative inter-practice and "pheno-pragma-practice" have been presented. Complementary, improvisation was described as an actualising form of a relational and creative pheno-practical inter-practice. Finally, the text outlined some practical, political, theoretical and methodological implications.

Putting into practice an integrally informed and creative inter-practice in organisations and management "pheno-pragma-practically" opens up important possibilities for the future study and practice of organisations. On the one hand this helps to critique disembodied and noncreative practices in which individual and collective bodies and embodiments are neglected, merely seen as constructed or rendered only as instrumentalised objects for an practicalistic focusing only on utilitarian issues at hand. Pheno-pragmatically such reductionistic approach is blocking the enfoldment of creative potentials of inter-practices and improvisational experimentalism. On the other hand, creative pheno-pragmatic inter-practices may contribute to the emergence and realisation of alternative, ingenious and more suitable and sustainable practices. This becomes even more relevant as these are situated in increasingly complex individual, collective, and organisational settings, calling in turn for engaging in more integral research practices.

Furthermore, actualising a creative and integral pheno-pragma practice may facilitate the cultivating of practical well-being and practical wisdom in organisations (Küpers, 2005a; Küpers, 2007) and a more relational, co-creative understanding of leader - and followership (Küpers \& Weibler, 2008). Moreover, through its unfoldment in organisational life-world, a pheno-pragmatic practice may also enable or mediate to enact more creative patterns and prudent inhabitualisations of socio-cultural and even intercultural post-ethnocentric practices 
towards more integral post-conventional and world-centric orientations. The phenomenologically and pragmatically based conceptualisation of "pheno-pragmatic" interpractices on a micro-level may then serve as a cultivating form for entering, processing and transforming life-worldly practices on a macro-level, unseparated;y connected to the former.

All in all the extended phenomenological pheno-pragmatic approach as outlined can be used to illustrate, highlight, interpret, deconstruct or re-conceive the experiential base for processualy practices of organising and managing. Leaving behind the dualistic and reductionistic approaches and re-searching the lived and living experience of practice is a challenging endeavour. Nevertheless this is a worthwhile undertaking as it can contribute for a much needed more integral and sustainable inter-practice in organisation and its study as well as beyond.

\section{Endnotes}

${ }^{1}$ For example for Habermas (1989): “Heidegger's methodical solipsism (...) prevents him, from taking seriously normative validity-claims and the meaning of moral obligations....Concrete history remained for him a mere "ontical" happening, social contexts of life a dimension of the inauthentic, propositional truth a derivative phenomenon, and morality merely another way of expressing reified values. Blind spots in Heidegger's innovative Being and Time can be explained in this way" (p. 439).

2 "Gelassenheit" refers to an ethos of active and ongoing passivity, to an accepting by letting-go, which implies an abandment of habitual, representational and calculative thinking and acting. As Ziarek (2002, p. 182) noted: "Lettingness is neither simply a human act nor a fate that humans accept and allow to be. Rather, letting has to be conceived in the middle voice beyond activity and passivity, the middle voice into which relations can be let. This letting, while not entirely at human disposition or will, needs to be worked on.... Lassen does not mean that humans transform being, that they enforce or make this transformation. Rather, it indicates that being transforms itself but cannot do so 'on its own', without human engagement, without human setting."

3 "Erlebnis" is a common German word, which has the normal connotation of event, occurrence, adventure, experience; something memorable, which happens to someone. It refers to lived experiences as we live through it and recognize it as a particular type of experience. In a way these experiences are simply experiences-as-we-live-through-it in our embodied actions, passions, relations and situations.

${ }^{4}$ For Wicks and Freeman (1998) pragmatism provides critical resources for highlighting the moral dimensions of organizing while at the same time avoiding entrenched epistemological distinctions that marginalize ethics and make research less useful, moving beyond the positivism vs. antipositivism debate and working from an alternative framework. For them pragmatism allows researchers to put this debate to the side and, in the process, develop 
research that is focused on serving human purposes, i.e., both morally rich and useful to organizations and the communities in which they operate.

5 Following Merleau-Ponty's $(1962,1995)$ focus on embodiment and inter-corporeality also Joas (1996) sees them as a constitutive precondition for creativity in action itself (Joas 1996, p. 163). As Joas showed together with situativeness and sociality corporeality reflect the embeddedness of actors and could be viewed as a "suitable replacement for the means-ends schema as the primary basic category of a theory of action" (1996, p. 160). Accordingly, action is based in pre-reflective dimension as a given of the world prior to all acts of reflection (Joas, 1996, p. 179). It is constituted by what the body is and does at a pre-conscious level (Joas, 1996, p. 184). Therefore any ability to act creatively rest on tacit assumptions and implications, particularly as embodied primary sociality. With these tacit embedments, all forms of creative practice are co-constituted and processed by implicit knowing (Küpers, 2005). Furthermore creativity and creative action is based not only on pre-reflective embodied, situated, but also social dimensions like sharing, recognition, communication. In creative practices action continually introduces novel possibilities in practical action, and passion as well as provokes a variety of individual and social responses.

${ }^{6}$ Merleau-Ponty (1962, p. 144) defines habit as: "knowledge in the hands, which is forthcoming only when bodily effort is made, and can- not be formulated in detachment from that effort. The subject knows where the letters are on the typewriter as we know where one of our limbs is, through knowledge bred of familiarity which does not give us a position in objective space." And that is the body "which understands in the acquisition of habit...To understand is to experience harmony between what we aim at and what is given, between the intention and the performance - and the body is our anchorage in a world." A habit is a sedimented effect of the past "that remains alive in the present, shaping perception, conception, deliberation, emotion and action" (Crossley 2001, p. 104) habits are moving equilibria and as creative principles also can generate innovative actions.

${ }^{7}$ According to James (1904, p. 534), "the relations that connect experiences must themselves be experienced relations, and any kind of relation experienced must be accounted as real as anything else in the system." Pragmatism emphasises not "substantial" beings, but embodied interrelations, connectedness, transaction and entanglements as constitutive of reality and the constitutive and qualitative dimensions of experience, similar to advanced phenomenology. Also neo-pragmatism, for example Putnam's neo-pragmatic "direct realism" (1999), aims to return to the way people actually experience the world, rejecting the idea of mental representations, sense data, and other intermediaries between the threefold cord of mind, body, and world in his famous "brain in a vat" thought experiment (a modernized version of Descartes' evil demon hypothesis). Building on a causal theory of reference to which words always refer to the kinds of things they were coined to refer to, thus the kinds of things their user or her ancestors experienced, Putnam argued that one cannot coherently state that one is a disembodied "brain in a vat" placed there by some "mad scientist." Showing that such a scenario is impossible it challenges metaphysical realism, which assumes the existence of a gap 
between how man conceives the world and the way the world really is. As man cannot have a "God's eye" view of reality, he is limited to his conceptual schemes. With his concept of an internal realism (Putnam, 1990) he follows the view that, although the world may be "causally" independent of the human mind, the structure of the world - its division into kinds, individuals and categories - is a function of the human mind, and hence the world is not "ontologically" independent. According to Putnam, there can be many correct descriptions of reality. However, no one of these descriptions can be scientifically proven to be the "one, true" description of the world. This does not imply relativism, for Putnam, because not all descriptions are equally correct and the ones that are correct are not determined subjectively. Consequently, Putnam's most recent works have focused on bringing philosophy out of its self-imposed shell and back to the world of ordinary people and ordinary social problems. The link to direct experience can also be found in neo-Deweyian Shusterman $(2000,2004)$, who by focusing on immediate, nondiscursive experience outlines a kind of pragmatism (of embodiment), which he calls somaesthetics.

8 Pheno-pragma-practice aims also for "overcoming" classical phenomenology and its underlying, limited ontological and epistemological assumptions and methodologies. Following an anti-essentialist critique against classical transcendental phenomenology, instead of reifying phenomena into external "objects" pheno-pragma-practice aims not to describe the "whatness" of a phenomenon but to approach the meaning relations involved. Thus, "essence" is a relational term that refers to intentionalities and responsiveness; that is to possible ways of encountering and relating before and while we understand or think them in conceptual thought or express them in language, as embodied action and language are "equiprimordial" (gleichursprünglich). Accordingly a pheno-practical approach informs us that our primary and usual way of being-inthe-world is pragmatic inter-action and inter-passion based on embodied personal, interpersonal as well as environmental and contextual dimensions.

${ }^{9}$ Holons are integrative "entities" or processes, which are both wholes and parts of bigger wholes at the same time (Koestler, 1967). As emerging events holons evolve to complex orders of whole/partness by virtue of specific dynamic patterns they exhibit. Furthermore, the holonconstruct is based on the distinctions between the higher (transcendence) and the lower (immanence) and between the dynamics of agency (preservation) and communion (adaptation) (Edwards, 2005). Holonically, practices in organisations are comprised of processes and structures, which are simultaneously autonomous and dependent, characterized by differentiation (generation of variety) and integration (generation of coherence). A holonic understanding utilises different lenses for understanding the occurrence of practices, including interior and exterior dimensions as well as spheres of individuality and communality. Accordingly, practices are occasions constituted by individual holons and collective holons, which have each their interior and exterior dimensions. Consequently, practices are multidimensional events, which are impacted by and tend either to a more "subjective" or a more “objective” identity (Küpers 2009).

${ }^{10}$ Calculative rationalities are employed in what Heidegger calls "calculative thinking" (das rechnende Denken) (1966, p. 46) as the thinking proper not only to the sciences and economics, 
but in the technological age respectively it is produced by a technological understanding of being. Calculative thinking, says Heidegger, "calculates," "plans and investigates" (1966, p. 46); it sets goal and wants to obtain them. It "serves specific purposes" (ibid., p. 46); it considers and works out many new and always different possibilities to develop. Despite this productivity of a thinking that "races from one aspect to the next"; despite the richness in thinking activities proper to our age, and testified by the many results obtained; despite our age's extreme reach in research activities and inquiries in many areas; despite all this, nevertheless, Heidegger states that a "growing thoughtlessness" (1966, p. 45) is in place and needs to be addressed. Being a kind of restless thinking directed toward manipulation, toward obtaining some specific result, calculative thinking does not pause to consider the meaning inherent in "everything that is." It is always on the move, is restless and it "never collects itself" (Heidegger, 1966, p. 46). In turn, the distinguishing meditative thinking [das besinnliche Denken], means to notice, to observe, to ponder, to awaken an awareness, an innocent looking and listening of what is actually taking place around us and in us, which requires patience and silence, being as well as doing. Meditative thinking does not estrange us from reality. On the contrary, it keeps us extremely focused on our reality, on the hic et nunc of our being, as placed "existence." If calculative thinking does not think beyond the usefulness of what it engages with, meditative thinking would notice and become aware of the fact that these devices are not just extremely useful to us. Heidegger's ontological critique of enframing (1999), the technological understanding of being which turns everything it touches into a mere resource, that is a historical "mode of revealing" in which things show up only as resources to be optimized. A technological understanding of being produces a "calculative thinking" which quantifies all qualitative relations, reducing all entities to bivalent, programmable "information," digitized data. Not following the "essentialistic" idea that technology rigidifies into destiny, an appropriate response to technology and the dominance of calculative thinking for is Gelassenheit, that is, releasement, equanimity, composure, or "letting-be" (see also Dalle Pezze, 2006). For Heidegger "Gelassenheit zu den Dingen” (ibid., p. 54), releasement toward things is an expression of a change in thinking, which then is not calculating or representing, but ponders the meaning involved and hidden behind what we are related to and engaged with.

${ }^{11}$ For understanding the background and relevance of improvisation as an intentional process Schütz's (1967) differentiation between 1) "in-order-to" motives of action and 2) "because of" components of the action will be helpful. The first one represents the meaning embedded in a project and its constituent elements (plans, goals, means etc.), while the second deeper and wide ranging motives refer to the actor's past experiences selectively evoked according to the existential circumstances at the moment (e.g., of making a decision). It is only the "because of" components which convey the ultimate meaning and thrust to the devising and performance of the action. The in-order-to project deals with the actor's explicit and conscious meaning in solving a problematic situation, while the "because-of" motives explain why and how a situation has been perceived as problematic in the first place. The "because-of" motives are tacit and lie in the background of the explicit project at hand. They fall outside the glance of rational, awake attention during the performance of the action. They could be inferred by an outsider, or made explicit by the actor, but only as a result of reflection after the fact. 
12 This kind of reversible embodied practice is realised "by actively developing our powers of reflective somatic consciousness so that we can achieve a higher unity of experience on the reflective level and thus acquire better means to correct inadequacies of our unreflective bodily habits" (Shusterman, 2005, p. 176). Interestingly, Shusterman suggests that pragmatism offers a complementary perspective to phenomenological approaches, in that it provides more adequately a "full-bodied engagement in practical efforts of somatic awareness... generating better experiences for the future rather than trying to recapture the lost perceptual unity of a primordial past" (Shusterman, 2005, p. 177).

${ }^{13}$ Merleau-Ponty's critique of the Cartesian metaphysics projects the possibility of a new, corporeal ontology that reflects the inextricable intertwining of the human "body-subject" with the world it inhabits in organisations. By acknowledging with Merleau-Ponty the intertwining inseparability of "object-knowledge" and "self-knowledge" in the midst of fields of "inbetweeness" chances for an aesthetic reflection, reversibility, receptivity and corresponding responsiveness become approachable. Merleau-Ponty's approach offers a real chance to work on organising aesthetics with a post-Cartesian epistemology. Merleau-Ponty regards phenomenology as a radical anti-foundational philosophy, which can alert us, to the fact that ideas are never absolutely pure thoughts but rather, cultural objects necessarily linked to acts of expression whose source is the phenomenal embodiment and emotionality itself as already primordially expressive. A critical phenomenology is one way of challenging sedimented assumptions and underlying structures of power contributing to find intepretative approaches to what and how phenomenal processes carry. Furthermore, Merleau-Ponty's sense of being in his indirect ontology of "flesh" and approach towards reversibility can be interpreted as a "pre-+post-+-modern" "return forward" into what he calls non-dual "Wild Being" of creativity. Just prior to collapse into complete non-duality there is this chiasmic point where the difference between the dualities begins to separate but have not yet gained the necessary escape velocity to tear apart. It is this thin space between the collapse of the antinomic opposites and the arrival at complete non-duality that Wild Being directs our attention toward. At this level we discover that there is something beyond the essencing and the eventity; a holon which is simultaneously whole and part. The holonic nature of the thing is a chiasm between the view of the thing from the outside as evenity and from the inside as "essential" epoch. We can think of the holon as establishing the chiasm between inside and outside and the integra as establishing the reversibility between different viewpoints on the same thing. These two approaches toward the thing together establish the "flesh," or "play," or "schizoid," or the "interactive heterogeneity and heterogeneous interactivity" by which the various philosophies of Wild Being describe the world.

${ }^{14}$ Polanyi (1966, 1969, p. 147) has already emphasised the role of the body in our contact to the world as the necessary somatic equipment, referring to "the trained delicacy of eye, ear, and touch" (Polanyi \& Prosch, 1975, p. 31). As Polanyi stated, "the way the body participates in the act of perception can be generalized further to include the bodily roots of all knowledge and thought. (...) Parts of our body serve as tools for observing objects outside and for manipulating them" (Polanyi, 1969, p. 147). However the status of Polanyi's body as a masculine, rationalinstrumental ideal, as standardised body of "man the knower" who is disengaged, emotionally 
under-control, lacking desire, isolated in its own performance and disassociated from itself need to be investigated critically. This includes other non-rational forms of knowing, e.g. carnal, affective, erotic, intuitive, and spiritual and situated power relations in the micro-morphological flows of perception, desire, and action, conducting the structure and dispositions for the knowledge in organisations. 
Phenomenology \& Practice, Volume 5 (2011), No. 1, pp. 100-139.

\section{References}

Adams C. \& Van Manen M. (2008). Phenomenology. In L.M. Given (Ed.), The Sage Encyclopedia of Qualitative Research Methods (pp. 614-619). Thousand Oaks, CA: Sage.

Aho, K. (2005). The missing dialogue between Heidegger and Merleau-Ponty: On the importance of the Zollikon seminars. Body and Society, 2(11), 1-23.

Aikin, S. (2006). Pragmatism, naturalism, and phenomenology. Human Studies, 29(3), September, 317-340.

Alexander, T. (1987). John Dewey's theory of art, experience and nature: The horizons of feeling. Albany, NY: State University of New York.

Arens, E. (1994). The logic of pragmatic thinking. From Peirce to Habermas. Atlantic Highlands: Humanities Press.

Bailey, D. (1992). Improvisation: Its nature and practice in music. New York: Da Capo Press.

Baker, T. and Nelson, R. (2005). Creating something from nothing: Resource construction through entrepreneurial bricolage. Administrative Science Quarterly, 50(3), 329-366.

Berry, D. C. (Ed.). (1997). How implicit is implicit learning? Oxford: Oxford University Press.

Bewes, T. (2002). Reification, or the anxiety of late capitalism. London: Verso.

Bourdieu, P. (1977). Outline a theory of practice. Cambridge: Cambridge University Press.

Bourdieu, P. (1990). The logic of practice. Stanford, CA: Stanford University Press.

Bradbury, H., and Lichtenstein, B.M.B. (2000). Relationality in organizational research: Exploring the space between. Organization Science, 11, 551-564.

Bromley, D. W. (2006). Sufficient reason: Volitional pragmatism and the meaning of economic institutions. Princeton, N.J.: Princeton University Press.

Ciborra, C. (1999). Notes on improvisation and time in organizations. Accounting, Management and Information Technology, 9(1), 77-94.

Crossan, M. M. (1998). Improvisation in action. Organization Science, 9(5), 593-599. 
Crossan, M. M., Lane, H.W., White, R.E., and Klus, L. (1996). The improvising organization: Where planning meets opportunity. Organizational Dynamics, Spring, 24(4), 20-35.

Crossan, M. \& Sorrento, M. (1997). Making sense of improvisation. In J.P. Walsh \& A.S. Huff (Eds.), Advances in Strategic Management, 14, 155-180.

Crossley, N. (2001). The social body: Habit, identity, and desire. London: Sage

Crossley, N. (2006). Reflexive embodiment in contemporary society, Buckingham: Open University Press.

Cunha, M. P., Cunha, J. V., \& Kamoche, K. (1999). Organizational improvisation: What, when, how and why. International Journal of Management Reviews, 1(3), 299-341.

Dale, K. (2001). Anatomising embodiment and organisation theory. London: Sage.

Dale, K. and Burrell, G. (2000). What shape are we in? Organization theory and the organized body. In J. Hassard, R. Holliday and H. Willmott (Eds.), Body and organization (pp. 15-30). London: Sage.

Dalle Pezze, B. (2006). Heidegger on Gelassenheit. Minerva - An Internet Journal of Philosophy, 10, 94-122.

Dalton, B. (2004). Creativity, habit, and the social products of creative action: Revising Joas, incorporating Bourdieu, Sociological Theory, 22(4), December, 2004, 603-622.

de Certeau, M. (1984). The practice of everyday life. Berkeley, CA: University of California Press.

Dewey, (1958). Experience and nature. Mineola, NY: Dover Publishing Inc.

Dewey, J. (1908). Does reality possess practical character. Essays in honor of William James. New York: Longmans.

Dewey, J. (1922). Human nature and conduct: An introduction to social psychology. New York: Modern Library.

Dewey, J. (1925). Experience and nature. South Bend: Open Court.

Dewey, J. (1931). Art and experience. New York: Scribners.

Doane, G.H. \& Varcoe, C. (2005). Toward compassionate action: Pragmatism and the inseparability of theory/practice. Advances in Nursing Science, 28(1), 81-90. 
Duymedjian, R. \& Rüling, C. C. (2010). Towards a foundation of bricolage in organization and management theory. Organization Studies, 31(2), 133-151.

Edie, J. (1987). William James and phenomenology. Indianapolis: Indiana University Press.

Edwards, M. G. (2005). The integral holon: A holonomic approach to organisational change and transformation. Journal of Organizational Change Management, 18(3), 269288.

Elkjaer, B. (2000). The continuity of action and thinking in learning: Re-visiting John Dewey. Critical Social Studies, 2, 85-101.

Elkjaer, B. \& Simpson, B. (2011.) Pragmatism: A lived and living philosophy. What can it offer to contemporary organization theory? In H. Tsoukas \& R. Chia (Eds.), Research in the Sociology of Organizations (pp. 55-84). Emerald Group Publishing Ltd.

Feldman, M. S., A. Rafaeli (2002). Organisational routines as sources of connections and understandings. Journal of Management Studies, 39(3), 309-331.

Gherardi, S. (2000). Practice-based theorizing on learning and knowing in Organizations. Organization, 7(2), 211-223.

Gillespie. G. (2005). G. H. Mead: Theorist of the social act, Journal for the Theory of Social Behaviour, 35(1), 19-39.

Giorgi, A. (1997). The theory, practice, and evaluation of the phenomenological method as a qualitative research procedure. Journal of Phenomenological Psychology, 28(2), 235-260.

Gunnlaugson, O. (2005). Toward integrally informed theories of transformative learning. Journal of Transformative Education, 3(4), 331-353.

Haack, S. (Ed.). (2006). Pragmatism old and new: Selected writings. Amherst, N.Y.: Prometheus.

Habermas, J. (1985). The philosophical discourse of modernity. Cambridge, MA: The MIT Press.

Habermas, J. (1989). Work and weltanschauung: The Heidegger controversy from a German perspective. Critical Inquiry, 15(2), Winter, 1989, 431-456.

Hacking, I. (1999). The social construction of what? Cambridge: Harvard University Press.

Hamrick, W. S. (1974). Whitehead and Merleau-Ponty: Some moral implications. Process Studies, 4(4), Winter, 235-251. 
Hancock, P. (2009). Management and colonization in everyday life. In P. Hancock \& M. Tyler (Eds.), The Management of Everyday Life (pp. 1-20). London: Palgrave.

Hassard, J., Holliday, R. and Wilmott, H. (2000). Body and organisation. London: Sage.

Hatch, M. J. (1999). Exploring the empty spaces of organizing: How improvisational jazz helps redescribe organizational structure. Organization Studies, 20(1), 75-100.

Heidegger, M. (1954). Vom Wesen der Wahrheit. Frankfurt: Klostermann.

Heidegger, M. (1959). Unterwegs zur Sprache. Stuttgart: Neske.

Heidegger, M. (1962). Being and time. New York: Harper \& Row.

Heidegger, M. (1966). Discourse on thinking. New York: Harper and Row.

Heidegger, M. (1993). The question concerning technology. In M. Heidegger, Basic Writings, (pp. 307-342). New York: Harper Collins.

Heidegger, M. (1999). Contributions to philosophy. Bloomington: Indiana University Press.

Holt, R. and Sandberg, J. (2011). Phenomenology and organization theory. In H. Tsoukas \& R. Chia (Eds.), Research in the Sociology of Organizations (pp. 215-249). Emerald Group Publishing Ltd.

Hoskin, D. M. (2011). Telling tales of relations: Appreciating relational constructionism. Organization Studies, 32(1), $47-65$.

Husserl, E. (1970). Crisis of European sciences and transcendental phenomenology. Evanston: Northwestern University Press.

Husserl, E. (1973). Zur Phänomenologie der Intersubjektivität. Zweiter Teil: 1921-1928, (Hua XIV) The Hague: Martinus Nijhoff.

Hyland, D. A. (1984). The question of play. New York: University Press of America.

James, W. (1895). The will to believe; and other essays in popular psychology. New York.

James, W. (1904). A world of pure experience. Journal of Philosophy, Psychology, and Scientific Methods, 1, 533-543, 561-570.

James, W. (1907). Pragmatism. A new name for some old ways of thinking. New York: Longmans.

Jarzabkowski, P. (2005). Strategy as practice. An activity-based approach. London: Sage. 
Jick, T. D. (1979). Mixing qualitative and quantitative methods: Triangulation in action. Administrative Science Quarterly, 24(4), 602-611.

Joas, H. (1993). Pragmatism and social theory. Chicago: University of Chicago Press,

Joas, H. (1996). Creativity of action. Chicago: University of Chicago Press.

Johnson, G. (2003). Merleau-Pontian phenomenology as non-conventionally utopian. Human Studies, 26, 383-400.

Kestenbaum, V., (1977). The phenomenological sense of John Dewey: Habit and meaning. Atlantic Highlands, N.J.: Humanities Press.

Kilpinen, E. (2000). The enormous fly-wheel of society: Pragmatism's habitual conception of action and social theory. Research Report Nr. 235, Department of Sociology, University of Helsinki.

Kilpinen, E. (2009). The habitual conception of action and social theory. Semiotica, Volume 2009(173), 99-128.

Koestler A. (1967). The ghost in the machine. London: Hutchinson.

Küpers, W. (2004). Learning organization and leadership. In J.M. Burns, R.R. Goethals \& G.J. Sorenson, G.J. (2004). Encyclopaedia of Leadership, (pp. 881-886). Thousand Oaks, CA: Sage.

Küpers, W. (2005). Phenomenology and pheno-pragma-practice of embodied implicit and narrative knowing. Journal of Knowledge Management, 9(6), 113-133.

Küpers, W. (2005a). Phenomenology and integral pheno-pragma-practice of embodied wellbe(com)ing in organizations. Culture and Organization, 11(3), September 2005, 221-231.

Küpers, W. (2007). Integral pheno-Practice of wisdom in management and organisation. Social Epistemology special issue on Wisdom and Stupidity, 22(4), 169-193.

Küpers, W. (2008). Embodied 'inter-learning'- An integral phenomenology of learning in and by organizations. The Learning Organisation: An International Journal, 15(5), 388-408.

Küpers, W. (2009). Perspective on integral 'pheno-pragma-practice' in organizations. International Journal of Management Practice, 4(1), 27-50. 
Küpers, W. (2010). Inter-places- embodied spaces \& places of and for leader-/followership phenomenological perspectives on relational localities \& tele-presences of leading and following. Environment, Space, Place Journal, 2(1), 79-121.

Küpers, W. (2011). Dancing on the limen - embodied in-between as inter-place of liminality in organisations. Tamara, Journal for Critical Organization Inquiry Special Issue on Liminality, 9(1)(forthcoming).

Küpers, W. (2011a). The senses of sense-ma(r)king - phenomenology of embodied aiesthesis in organisation. Ian King (Ed.), The Sensational Organization New Directions for Sensing, Perceiving and Imagining Organizational life, Faringdon Oxfordshire: Libri (forthcoming).

Küpers, W. (2012). Integral responsibility and sustainability in organisation and management. In G. Eweje \& M. Perry (Eds.), Business and Sustainability Concepts, Controversies and Cases. (forthcoming).

Küpers, W. \& Edward, M. (2008). Integrating plurality - towards an integral perspective on leadership and organisation. In C. Wankel, (Ed.), (2008). Handbook of 21st Century Management (pp. 311-322). London: Sage.

Küpers, W. \& Weibler, J. (2008). Inter-leadership - why and how to think leader- and followership integrally. Leadership, 4(4), 443-47.

Leder, D. (1990). The absent body. Chicago: University of Chicago Press.

Machin, D. \& Carrithers, M. (1996). From "interpretative communities" to "communities of improvisation." Media Culture and Society, 18, 343-352.

McDermid, D. (2006). The varieties of pragmatism: Truth, realism, and knowledge from James to Rorty. London and New York: Continuum.

Mead, G. H. (1938). Philosophy of the act. Chicago: The university of Chicago Press.

Merleau-Ponty, M. (1962). Phenomenology ofpPerception. London: Routledge.

Merleau-Ponty, M. (1964). Signs. Richard C. McCleary (Trans.). Evanston: Northwestern University Press.

Merleau-Ponty, M. (1995). The visible and the invisible. Evanston: Northwestern University Press.

Miner, A. S., Bassoff, P., \& Moorman, C. (2001). Organizational improvisation and learning: A field study. Administrative Science Quarterly, 46, June, 304-337.

Mirvis, P. H. (1998). Practice improvisation. Organization Science, 9(5), 586-592. 
Montuori, A. (2003). The complexity of improvisation and the improvisation of complexity: Social science, art and creativity. Human Relations, 56(2), 237-255.

Nachmanovitch, S. (1990). Free play: Improvisation in life and art. New York: Putnam.

Napolitano, V. \& Pratten, D. (2007). Michel de Certeau: Ethnography and the challenge of plurality. Social Anthropology, 15(1), 1-12.

Nicolini, D., Gherardi, S., \& Yanow, D., (Eds.). (2003). Knowing in organizations: A practice-based approach. Armonk: Sharpe.

Nicolini, D., Gherardi, S., \& Yanow, D. (2003). Introduction. In D. Nicolini, S. Gherardi \& D. Yanow (Eds.), Knowing in organizations: A practice-based approach (pp. 3-31). Armonk: Sharpe.

Orlikowski, W. J. (1996). Improvising organizational transformation over time: A situated change perspective. Information Systems Research, 7(1), 63-92.

Orlikowski, W. J. \& Hofman, J.D. (1997). An improvisational model for change management: The case of groupware technologies. Sloan Management Review, $38(2), 11-21$.

Orlikowski, W.J. (2002). Knowing in practice: Enacting a collective capability in distributed organizing. Organization Science, 13(4), 249-273.

Ostrow, J. (1990). Social sensitivity: A study of habit and experience. Albany: State University of New York.

Ott, H. (1993). Martin Heidegger: A political life (Allan Blunden, Trans.). New York: Basic.

Peirce, C.S. (1931-58). The collected papers of Charles Sanders Peirce, C. Hartshorne, P. Weiss (Vols. 1-6) and A. Burks (Vols. 7-8) (Eds.). Cambridge, MA: Harvard University Press.

Pinnington, A., Morris, T. \& Pinnington, C. (2003). The relational structure of improvisation. International Studies of Management \& Organization, 33(1), Spring, 10-33.

Polanyi, M. (1966). The tacit dimension. London: Routledge.

Polanyi, M. (1969). Knowing and being. Essays by Michael Polanyi. Chicago: The University of Chicago Press.

Polanyi M., \& Prosch H. (1975). Meaning. Chicago: University of Chicago Press. 
Putnam, H. (1990). Realism with a human face. James Conant (Ed.). Cambridge, Mass.: Harvard University Press.

Putnam, H. (1999). The threefold cord: Mind, body, and world. New York: Columbia University Press.

Reason, P., \& Bradbury, H. (Eds.). (2001). Handbook of action research: Participative inquiry and practice. London: Sage Publications.

Reber, A. (1993). Implicit learning and tacit knowledge. New York: Oxford University Press.

Rescher, N. (2000). Realistic pragmatism. An introduction to pragmatic philosophy. Albany: SUNY Press.

Rosenthal, S. B. (1980). Pragmatism and phenomenology: A philosophic encounter. Amsterdam: Grüner.

Sandberg, J., \& Dall'Alba, G. (2009). Returning to practice anew: A life-world perspective. Organization Studies, 30(12), 1349-1368.

Schalow, F. (2006). The incarnality of being: The earth, animals, and the body in Heidegger's thought. Albany: State University of New York Press.

Schatzki, T. (1996). Social practices: A Wittgenstenian approach to human activity and the social. New York: Cambridge University Press.

Schatzki, T. (2006). On organizations as they happen. Organization Studies, 27(12), 18631873.

Schatzki, T., Knorr Cetina, K. \& Von Savigny, E. (Eds.). (2001). The practice turn in Contemporary Theory. London: Routledge.

Schmidt, V.H. (2001). Oversocialised epistemology: A critical appraisal of constructivism. Sociology, 35(1), 135-157.

Schutz, A. (1967). The phenomenology of the social world. Evanston: Northwestern University Press.

Segal, S. (2010). A Heideggerian approach to practice-based reflexivity. Management Learning, 41(4), 379-389.

Shilling, C. (1993). The body and social theory. London: Sage.

Shilling, S. (2008). Changing bodies: Habit, crisis and creativity. London: Sage. 
Shook, J. R. \& Margolis, J. (2006). A companion to pragmatism. Malden, Mass.: Blackwell.

Shusterman, R. (2000). Somaesthetics and the body/media issue. In R. Shusterman (2000). Performing live, aesthetic renewals to the ends of art (pp. 137-153). New York, NY: Cambridge University Press.

Shusterman, R. (2004). Somaesthetics and education. In Liora Bresler, Knowing bodies, moving minds. Towards embodied teaching and learning (pp. 51-60). Dordrecht/Boston/London: Kluwer Academic Publishing.

Shusterman, R. (2005). The silent, limping body of philosophy. In T. Carman, M. Hansen. The Cambridge Companion to Merleau-Ponty (pp. 151-180). Oxford: Blackwell.

Shusterman, R. (2008). Body consciousness: A philosophy of mindfulness and somaesthetics. New York: Cambridge University Press.

Simpson, B. (2009). Pragmatism, Mead and the practice turn. Organization Studies, 30(12), 1329-1347.

Styhre, A. (2004). Rethinking knowledge: A Bergsonian vritique of the notion of tacit knowledge.' British Journal of Management, 15(2), June 2004, 177-188.

Swidler, A. (2001). What anchors cultural practices? In T. Schatzki, K. Knorr-Cetina, E. Savigny von (Eds.). The practice turn in contemporary theory (pp. 74-92). London/New York: Routledge.

Tharp, T. (2003). The creative habit: Learn it and use it for life. New York: Simon \& Schuster.

Thayer, H. S (1981). Meaning and action. A critical history of pragmatism. Indianapolis: Hackett Publishing.

Torbert, W. \& Associates (2004) Action inquiry: The secret of timely and transforming leadership. San Francisco: Berrett-Koehler.

Turner, V. (1969). The ritual process: Structure and anti-structure. Ithaca, NY: Cornell University Press.

van Manen, M. (1991). The tact of teaching: the meaning of pedagogical thoughtfulness. Albany, NY: State University of New York.

van Manen, M. (1997). Researching lived experience: Human science for an action sensitive pedagogy (2nd ed.). London, ON: Althouse Press. 
van Manen, M. (2007). Phenomenology of practice. Phenomenology \& Practice, 1(1), 11 30.

van Manen, M. \& Adams, C. (2010). Phenomenological research. In Craig Kridel (Ed.), Encyclopedia of Curriculum Studies. Thousand Oaks, CA: Sage

Vannini, P. \& Waskul, D. (2006). Body ekstasis: Socio-semiotic reflections on surpassing the dualism of body-image. In Dennis Waskul and Phillip Vannini (Eds.), Body/embodiment: Symbolic interaction and the sociology of the body (pp. 183-200). Aldershot: Ashgate.

Yanow, D. \& Tsoukas, H. (2009). What is reflection-in-action? A phenomenological account. Journal of Management Studies, 46(8), 1339-1364.

Vera, D. (2002). Improvisation and its impact on performance. London, ON: University of Western Ontario.

Waldenfels, B. (2007). The Question of the Other. Hong Kong: Chinese University of Hong Kong.

Weick, K. (2003). Theory and practice in the real world. In H. Tsoukas \& C. Knudsen (Eds.), The Oxford handbook of organization theory (pp. 453-75). Oxford: Oxford University Press.

Weick, K. E. (1995). Sensemaking in organizations. Thousand Oaks, London, New Delhi:Sage.

Weick, K. E. (1998). Introductory essay - Improvisation as a mindset for organizational analysis. Organization Science: A Journal of the Institute of Management Sciences, $9(5), 543-555$.

Weik, E. (2004). From time to action. Time \& Society. 13(2/3), 301-319.

Weiner, R. P. (2000). Creativity \&beyond. Cultures, values, and change. New York: State University of New York Press.

Weiss, G. (2008). Can an old dog learn new tricks? Habitual horizons in James, Bourdieu and Merleau-Ponty. In G. Weiss, G. (Ed.). (2008). Intertwinings: Interdisciplinary encounters with Merleau-Ponty (pp. 223-240). Albany: SUNY Press.

Whittington, R. (2003). The work of strategizing and organizing: for a practice perspective. Strategic Organization, 1, 117-125.

Whittington, R. (2006). Completing the practice turn in strategy research. Organization Studies. 5, 613-634. 
Wicks, A.C. \& Freeman, R.E. (1998). Organization studies and the new pragmatism: Positivism, anti-positivism, and the search for ethics. Organization Science, 9(2), 123-140.

Yin, R. K. (1994). Case study research: Design and methods (2nd ed.). Thousand Oaks, CA: Sage.

Ziarek, K. (2002). Art, power, and politics: Heidegger on machenschaft and poiêsis. Contretemps, 3, 175-85. 